\title{
A Pragmatic Analysis of Impoliteness in Selected Ghanaian Social Interactions
}

\author{
Dorcas Oteng Acheampong $18(\mathrm{D}) \square$ and Michael Kwarteng $28(\mathrm{D}$ \\ ${ }^{7}$ M.A. Foreign Linguistics and Applied Linguistics, Department of Applied Linguistics, Nanjing Tech University, Nanjing, China \\ ${ }^{2}$ M.A. Foreign Languages and Literature, Department of Applied Linguistics, Nanjing Tech University, Nanjing, China \\ $\triangle$ Corresponding Author: Dorcas Oteng Acheampong, E-mail: nanaadebi32@gmail.com
}

\section{ARTICLE INFORMATION \\ Received: February 14, 2021 \\ Accepted: March 01, 2021 \\ Volume: 3 \\ Issue: 3 \\ DOI: $10.32996 /$ jeltal.2021.3.3.5}

\section{KEYWORDS}

Impoliteness, face threatening act, strategy, response

\section{ABSTRACT}

This study investigates impolite natural Ghanaian conversations using a pragmatic approach. It is aimed at describing the types of impoliteness strategies, how they are linguistically represented and identifying responses toward the impoliteness strategies. This research employed a qualitative collection. The data were ten natural Ghanaian conversations which portray a distinct Ghanaian society in terms of norms, relationship, status and power. The sources of the data were documented transcribed into English because some were in the local language (Twi). In this research, descriptive and investigative approach was used in analyzing the data. The results of this research are stated as follows. The five types of impoliteness strategies are used by interlocutors in the conversations. They are, positive impoliteness, negative impoliteness, sarcasm or mock politeness, withhold politeness and bald-on-record impoliteness. Negative impoliteness is the most dominant type of impoliteness strategy, while positive impoliteness is the least strategy to occur in this research. The impoliteness strategies were linguistically represented by the use of vocatives, dismissal, threats and silencers. Accepting impoliteness is the most frequently used response. The interlocutors choose to use this response because they tend to prevent any further face attack.

\section{Introduction}

Impoliteness is not just the opposite of politeness, but the manifestation of non-cooperation, disapproval, and mutual antipathy through certain communicative behaviors that signal disrespect (Thompson \& Agyekum, 2016). Impoliteness is a field in pragmatics which is now gaining much attention and researchers are diving into it. For a long time, it had been either overlooked or simply considered as pragmatic failure to observe the politeness principles (Leech, 1983; Brown \& Levinson, 1987; cited in Limberg, 2009). Compared to politeness that has been analyzed for almost five decades, impoliteness has only been explored quite recently. This could be because it has been ignored as it is considered an offensive linguistic behaviour, and is the 'parasite of politeness' (Culpeper, 1996). According to Limberg (2009), a speaker may intentionally employ a communicative strategy to cause a social conflict with the addressee. A speaker can make an utterance without taking into consideration the hearer's face or social identity.

Impoliteness provides an umbrella term to cover a range of face-threatening acts (FTAs) (Brown \& Levinson, 1987) such as rudeness, aggression and intimidation, which reflect speaker intentionality, purposiveness and hearer perception (Culpeper, 2005; Bousfield, 2008). Culpeper (1966) is very prominent in this field whose model of impoliteness was initially introduced as a parallel to Brown and Levinson's (1987) theory of politeness identified five super impoliteness strategies of face threatening acts interlocutors employ in a discourse; bald on record, positive, negative, sarcasm and withhold which speakers adopt consciously or unconsciously to convey a message.

As a communicative strategy, impoliteness is not used without reasons. Bousfield (2007a) has argued that impoliteness does not exist in a vacuum and that the interlocutors must have felt sufficiently provoked at some point prior to delivering the utterance

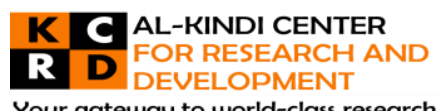

Your gateway to world-class research

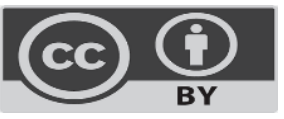

Published by Al-Kindi Center for Research and Development, United Kingdom. Copyright (c) the author(s). This open access article is distributed under a Creative Commons Attribution (CC-BY) 4.0 license 
containing impoliteness. Impolite utterances are not just made. There are varieties of factors that serve as a trigger mechanism, including time, place, social class and age on the side of both interlocutors.

Impoliteness linguistically manifests as face threatening act and this comes in different forms and shades including insult swear words, taboo words and criticism. Generally, any type of direct acts such as attacks, verbal aggression, insults or severe criticism, which damage face by the use of some adjectives and imperative forms of verbs, can be classified as impolite Nur (2006). The interpretation of statement depends on linguistic forms like various stylistic devices, irony, and metaphors in a context.

This study is to identify the kind of impoliteness strategies used, the factors influencing it and how they are linguistically represented

\section{Literature Review}

This chapter includes the definition of key concepts, theoretical framework and other related empirical studies on impoliteness.

\subsection{Impoliteness}

Impoliteness is any type of communicative behaviour that is assessed as an intention to threaten an addressee's face or social identity or intend to transgress the norms and values of a particular community (Bousfield, 2008a, b). Kangrai (2013) asserts that impoliteness can only happen when the speaker communicates face- attack intentionally or the hearer perceives and or construct behaviour as intentionally face - attacking or the combination of the two. This means an utterance can be said as impolite based on the interlocutors taking into consideration the time, place,age, social class, relationship, culture, etc. There are some societal norms that speech participants are expected to adhere to in a communicative event. Based on Brown and Levinson's model of politeness strategy, Culpeper (1996) writes a seminal article on impoliteness. He identified impoliteness as "the parasite of politeness" (1996, pp. 8) and the politeness strategies are the opposite of impoliteness strategies. The opposite here refers to its orientation to face. Politeness strategy is utilized to enhance or support face which social disharmony. As Culpeper (1996: 8) defines impoliteness as the use of strategies to attack the interlocutor's face and create social disruption.

It is difficult to give a precise definition to impoliteness since it is related to the context as well as the social values because some verbal behaviors are interpreted to be polite in one situation and impolite behavior in another situation. In this case, impoliteness concept is based on the hearer's perception of what the speaker does, more than the speaker's actual behavior.

\subsection{The Concept of Face}

The concept of face is a central concept in studying linguistic politeness and impoliteness. Erving Goffman originally introduced this concept in the 1960s, and he acknowledges that the concept was originated from Chinese culture. Goffman (1967)defines face as the positive social value a person affectionately claims for himself by the line others assume he has taken during a particular contact. He implies that our face is a personality we project during a conversation. It is not constant and it is subject to change in a particular situation. An example is a woman presenting herself as a mother in a situation and in another situation as a wife.

\subsection{Impoliteness Strategies}

Based on Brown and Levinson's model of politeness strategy Culpeper (1996) writes a seminal article on impoliteness. He identified impoliteness as "the parasite of politeness" $(1966, \mathrm{pp} .8)$ and the politeness strategies are the opposite of impoliteness strategies. The opposite here refers to its orientation to face. Politeness strategy is utilized to enhance or support face which can avoid conflict while impoliteness strategies are used to attack face which cause social disharmony. As Culpeper (1996, pp. 8) defines impoliteness as the use of strategies to attack the interlocutor's face and create social disruption. Culpeper proposes five super strategies that speakers use to make impolite utterances as follows: bald on record impoliteness (shout), positive impoliteness (insults, criticism, disagreements, ignore, snub, unsympathetic), negative impoliteness, sarcasm(using indirect offense), withhold politeness(failing to be polite when it is expected).

Bald on record impoliteness

The FTA is performed directly, clear, unambiguous, and concisely in circumstances where face is not irrelevant or minimized (Culpeper, 2005). It is important to distinguish this strategy from Brown and Levinson's bald on record. For Brown and Levinson bald on record is a politeness strategy in fairly specific circumstances. For example,when face concerns are suspended in an emergency, when the threat to the hearer's face is very small (e.g. "Come in" or "Do sit down"), or when the speaker is much more powerful than the hearer (e.g. "Stop complaining" said by a parent to a child. In all these cases little face is at stake, and, more importantly, it is not the intention of the speaker to attack the face of the hearer.

Positive impoliteness.

The use of strategies designed to damage the addressee's positive face wants. This can be done through the following ways:Ignore, snub the other that fails to acknowledge the others' presence or capability. Exclude the other from an activity, 
disassociate from the other - for example, deny association or common ground with the other; avoid sitting together. Be disinterested, unconcerned, unsympathetic. Use inappropriate identity markers to use title and surname when a close relationship pertains, or a nickname when a distant relationship pertains. Use obscure or secretive language for example, mystify the other with jargon, or use a code known to others in the group, but not the target. Seek disagreement - select a sensitive topic. Make the other feel uncomfortable for example, do not avoid silence, joke, or use small talk. Use taboo words - swear, or use abusive or profane language. Call the other names - use derogatory nominations (Culpeper, 1996, p. 357).

\subsection{Negative Impoliteness}

This strategy is used to attack the addressee's negative face wants. This can be done through the following ways, such as: Frighten - instill a belief that action detrimental to the other will occur, condescend, scorn or ridicule that is to emphasize your relative power. Be contemptuous, do not treat the other seriously or belittle the other (e.g. us diminutives). Invade the other's space - literally (e.g. position yourself closer to the other than the relationship permits) or metaphorically (e.g. ask for or speak about information which is too intimate given the relationship). Explicitly associate the other with a negative aspect - personalize, use the pronouns 'I' and 'you'. Put the other's indebtedness on record -with a negative aspect, put the other's indebtedness on record (Culpeper, 1996, p. 358).

\subsection{Sarcasm or Mock politeness}

The Face threatening act (FTA) is performed with the use of politeness strategies that are obviously insincere, and thus remain surface realizations. Culpeper's sarcasm or mock politeness is close to Leech's (1983) conception of irony "If you must cause offence, at least do so in a way which doesn't overtly conflict with the politeness principle, but allows the hearer to arrive at the offensive point of your remark indirectly, by way of an implicature" (1983, pp. 82). This is of course the opposite of Brown and Levinson's social harmony that is achieved through off-record impoliteness. One more point to add is that 'sarcasm' (mock politeness for social disharmony) is clearly the opposite of 'banter' (mock impoliteness for social harmony) (Culpeper, 1996, p. 356).

\subsection{Withhold Politeness}

This refers to the absence of politeness work where it would be expected. For example, failing to thank somebody for a present may be taken as deliberate impoliteness. (Culpeper, 1996, p. 8-9). To Culpeper, Brown and Levinson touch on the face-damaging implications of withholding politeness work by saying that "...politeness has to be communicated, and the absence of communicated politeness may be taken as the absence of a polite attitude". Culpeper's super strategies of impoliteness are further investigated and elaborated by Bousfield (2008) with four super strategies. He believes that these four do not fall under the super strategies in Culpeper's (1996) model. Bousfield (2008, pp. 260-261) defines impoliteness as being the opposite of politeness, in that, rather than seeking to mitigate face-threatening acts (FTAs), impoliteness constitutes the issuing of intentionally gratuitous and conflictive verbal face-threatening acts (FTAs).

\subsection{Linguistic Representation of Impoliteness}

At a basic level, an impolite act is a function of the anticipated polite act, in which case impoliteness is rather a lack of tact, the absence of politeness. From this point of view, it is relatively easy to describe, roughly speaking, an impolite act. What is not very obvious is how to distinguish impoliteness from rudeness on the linguistic level. Because, for example, in the event of the use of certain linguistic forms like various stylistic devices, irony, metaphors, or a register of language like slang, the interpretation of the statements depends strictly on the context and conditions of enunciation. Such as, in the army, the use of imperative forms without any softeners will not be perceived as impoliteness or rudeness Nur (2006). Let's consider this example, you are not very good at drumming, this implies you know how to drum but not too much. The adjective very softens just a little brutality of the judgement. Obviously, there is a threat but it is blurry conveyed and slightly ambiguous. Culpeper (1996) claimed that swear words or profanity can attack others' positive face. This could be because they are developed on the basis of taboo categories, which are sanctioned and restricted on both institutional and individual levels (Andersson \& Trudgill, 2007). When spoken, they insult, threaten the face, and injure the persons being the target (Jay, 2000).

Culpeper (2011) identifies most frequent linguistic ways of causing impoliteness which include the use of vocatives (moron , plonker dickhead ,etc. You fucking, rotten, dirty, fat, etc. Burk, pig, shit, bastard, loser, etc.), personal negative evaluations (you're nuts, nuttier than a fruit cake, hopeless, pathetic, stupid etc., you can't do anything right), Dismissals (get lost / out, fuck / piss off), silencers (shut it / your mouth, face / etc., shut the fuck up), threats (I'll / I'm /we're gonna smash your face in, beat the shit out of you, box your ears, bust your fucking head off / etc.).

\subsection{Response to Impoliteness}

With regards to the occurrence of impoliteness activity, there are inherently two ways to encounter impoliteness: to respond and to not respond (Culpeper et al., 2003; Bousfield, 2008). The latter (no respond) does not need any further explanation. A 
response to impoliteness may happen in various ways. The first way is to accept the impoliteness and submit to the other thus ending the situation. The second way is that one may counter either in defensive or offensive way. Offensive strategies are intended to match or escalate. These are the impoliteness super-strategies that have been defined by Culpeper (1996) and Bousfield (2008). Meanwhile, the defensive strategies respond to a face attack is done by defending one's own face (Culpeper et al., 2003). These strategies include direct contradiction, abrogation, opt out on record, insincere agreement and ignore the attack. In short, responding to impoliteness can be done in one of the following ways, namely: (1) Not responding (2) Accepting impoliteness (3) Countering defensively, and (4) Countering offensively.

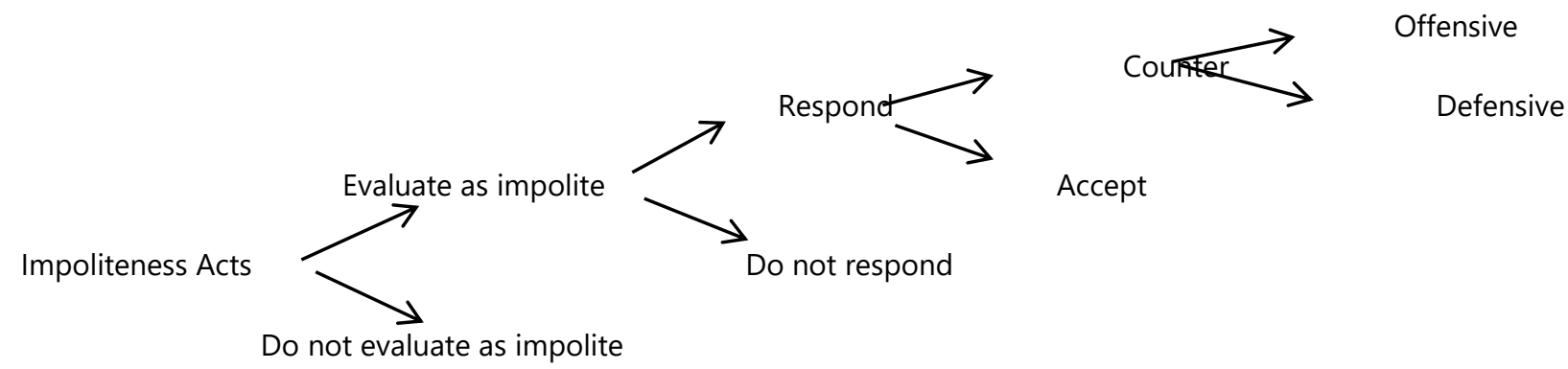

Along with theoretical frameworks developed to elaborate the concept of impoliteness, it has been the focus of a large number of empirical studies. Various forms of offensive language have been investigated in military discourse (Culpeper, 1996), political discourse (Harris, 2001; Garcia -Pastor, 2008), and legal discourse (Harris, 1984; Archer, 2011). Furthermore, a large number of researchers have given particular attention to several speech acts such as requests (Félix-Brasdefer, 2006), complaints (Perelmutter, 2010), invitations (Bella, 2011), and disagreement (Sifianou, 2012; Zhu, 2014). Some scholars also tried to shed light on the impoliteness in various literary works (Brown \& Gilman, 1989; Culpeper, 1998; Ermida, 2006; Rudanko, 2006; Metthias, 2011). On the other hand, the realization of impoliteness phenomena has been investigated in e-mail communications (Cehjnová, 2014), internet discussion forums (Shum \& Lee, 2013) and academic blog discussions (Luzón, 2013).

Furthermore, a number of scholars have also studied politeness strategies in a social discourse. In this sense that Abbas A.N, AlMajdawi A.M(2018) in their study asserts that Impoliteness in selected British social interviews is a process structured of three stages. The first stage is the pre impoliteness stage embraces violating the cooperative principle maxims. The second stage, the impoliteness stage, encompasses Culpeper's impoliteness strategies. The third stage, the post impoliteness stage,which is composed of the conflict termination.

Moreover, a study by Wijayanto et al. (2017) explored intentions and reasons for using impoliteness in EFL complaints. Based on the data elicited by retrospective interviews, researchers obtained a number of explanations regarding the intentions and triggers of impoliteness. In some cases, impoliteness is deployed by speakers to exercise their power by which they can have other collocutors do what they intend, such as making them well behaved, enforcing discipline, and demanding responsibilities. The reasons for involving impoliteness in the complaints provided the better understanding that impoliteness can be triggered by a number of factors including age, intimacy, social power, setting and conflict of interest occurring in specific contexts.

Also a study by Forson et al. (2017) highlighted the various motivations behind the use of abusive language in a Ghanaian society. These motivation includes intimidation, to ridicule, to cover inadequacies and to project one's self image. The study also revealed that the linguistic representations, including insults, taboo words, and criticisms that thrives on tender emotions, are highly dependent on context, emotions, personality status, and wit's strategic development.

What is perceived as impoliteness ultimately relies on interlocutors' assessment of the social norm of appropriateness. Impoliteness are dynamically negotiated by a variety of factors that is age, time, place, social class, attitudes and emotions. That means what can be considered as impolite in a situation can be polite in another situation. Impoliteness can also be measured by how it linguistically represented (insults, threats, criticism and the use of adjectives). For instance, if you tell a Ghanaian 'wagyimi pa ara' (you are very stupid), the person might respond defensively or offensively because it is one of the highest form of insult.

The work of impoliteness thus far has been devoted to theorizing and observing impoliteness in a number of domain such as social interviews (Abbas \& Al-Majdawi, 2016), court room interactions (Kryk-Kastovsky, 2006), in Ghana media (Fordjour, 2016), in TV shows (Culpeper, 2005), in political speech conflicts (Kienpointner, 2008), and in email exchanges (Haugh, 2010) among others. Despite the growing body of literature on impoliteness, little attention has been given to impoliteness employed in Ghanaian social interactions. Though studies have explored this area, they confined to examine the perception of impoliteness. 
This study will investigate the impoliteness strategies used by interlocutors, the factors influencing them and how they are linguistically represented in a social interaction.

\subsection{Research Gap}

Despite the growing body of literature on impoliteness, little attention has been given to impoliteness employed in Ghanaian social interactions

\section{Methodology}

The research answers the following questions:

1. Do the interlocutors employ any impoliteness strategies?

2. How is impoliteness linguistically represented by the speaker and the hearer?

3. What was the response to the impoliteness strategy used?

Qualitative data collection with a natural approach is employed in this study. Ten natural conversations in both English and Ghanaian language (Twi) depict impoliteness as documented and transcribed. The content of the data portrays a distinct Ghanaian society in terms of norms, relationship, status and power. It also contains linguistic forms such as vocatives, threats, silencers, dismissals and criticism for varied reasons and motivation.The data was analyzed based on Culpepper's (1996) impoliteness theory. The study employed qualitative analysis because it is explanatory and investigative in nature.

\section{Results and Discussion}

\subsection{Negative Impoliteness}

Culpeper (2005, pp. 41) is of the view that, this strategy is used to attack the addresses negative face wants to have freedom of action. Frightening the other, belittling, ridiculing, condescending and invading others space are output strategies of negative impoliteness

(a conversation between a host and panel on ponzy scheme)

Host : Will you still have your money?

Panel 1 : Yes, else Nana Addo won't complete his term

Panel $2 \quad$ : You are threatening the President. Please I cannot be a witness of this

(A boy reports a friend who beat him to his mother. She confronts him)

Mother $\quad$ Why did you beat my son? If you dare touch my son again,
I wont take it lightly with you
Son's friend : He was making fun of me ( he cries)

( two friends meets at a party with their kids and this what ensued between them)

Speaker 1 : What is the name of your daughter?

Speaker 2 : $\quad$ She is Ruth

Speaker $1 \quad$ : Ruth? Do we still name Ruth these days?

Speaker $1 \quad$ : Why do you want to disgrace us in public. I am not happy with this at all

The first example communicates threat. Panel 1 invests in a ponzy scheme and when the host asked if he will still have his money back, he threatens the president of what could happen to him if he does not get back his money "Yes, else Nana Addo won't complete his term". the second panelist accepted the impoliteness prompts him and counters it defensively immediately disassociate herself from the statement.

In the second example, the woman attacks the boy's negative face by threatening him not to repeat the action. She uses 'if you dare" to incites some sort of fear in him. The boy responds defensively by explaining to her what made him beat his friend " he was making fun of me" and cries to show disappointed he is in his friend's mum for just attacking him without making him speak. 
The third example is a form of ridicule.Recently, people have been making fun of even adults with old fashioned names. Speaker 1 expresses some kind of disappointment in her friend for naming her kid Ruth which seems to be an old name in the Ghanaian setting "Ruth? Do we still name Ruth these days?" therefore attacking the negative face of both mother and daughter. The speaker 2 least expected her friend to do that publicly. Speaker 2 counters it defensively in the expression "why do you want to disgrace us in public. I am not happy with this at all".

\subsection{Positive Impoliteness}

Positive impoliteness strategy comes in the form of ignoring the other, being disinterested, showing unconcerned, unsympathetic, using taboo words, obscure, secretive language, inappropriate identity markers.

(A gentleman meets a lady at a bus stop and ask for a seat)

$\begin{array}{ll}\text { Gentleman } & : \text { Do you mind if I sit beside you? } \\ \text { Lady } & : \text { You cant sit here } \\ \text { Gentleman } & : \text { Okay, don't mind }\end{array}$

The lady performs positive impoliteness as s fails to sympathize with the gentleman offering him a seat. She attacks his face want which she was supposed to notice and accept. As a response, the gentleman just accepts the face attack. He expresses it by saying "okay, don't mind" agreeing with her for failing to offer a seat.

\subsection{Mock Impoliteness}

According to Culpeper (1996) face threatening act in mock impoliteness is performed by means of implicature in a certain way that allows the hearer to arrive at the offensive point of an indirect remark.

(A conversation between colleagues during a lunch time)

$$
\begin{aligned}
& \text { Colleague } 1 \text { : What will you eat? } \\
& \text { Colleague } 2 \text { : Anything goes } \\
& \text { Colleague } 1 \text { : Then let's go and catch lizards and eat } \\
& \text { Colleague } 2 \text { : You are not normal }
\end{aligned}
$$

(A conversation between a son and a mother ready to go out)

$\begin{array}{lll}\text { Son } & : & \text { Where are we going mum? } \\ \text { Mum } & : & \text { We are going to the bank } \\ \text { Son } & : & \text { To do what? } \\ \text { Mum } & : & \text { To buy biscuits and toffees } \\ \text { Son } & : & \text { (Giggles...) }\end{array}$

In example 1 it can be deduced that colleague 1 needed a specific answer to the question he asked "what will you eat?". "Anything goes wasn't an answer he was expecting. He wanted an answer like I will eat rice or banku or fufu (staple foods). Lizards are not taking as food or meat in Ghana so colleague 2 felt offended and responded by countering it offensively saying "you are not normal".

Going to the bank has to do with money issues, so the mum least expected her son to ask such question "To do what? When she said they were going to the bank. She employs a mock impoliteness " to buy biscuits" for the son to realize he needed not to ask that question. The son accepted the impoliteness and responded by giggling and did not counter it.

\subsection{Withhold Impoliteness}

This refers to the absence of politeness work where it would be expected. For example, failing to thank somebody for a present may be taken as deliberate impoliteness (Culpeper, 1996, p. 8-9).

(A young girl meets an elderly woman with load, she greets and passes by)

$\begin{array}{lll}\text { Girl } & : & \text { Good afternoon mum (passes by) } \\ \text { Woman } & : & \text { Good afternoon. so wont you help your mum? It is okay }\end{array}$


(Three students passes in front of a man's house and greets )

$\begin{array}{lll}\text { Students } & : & \text { Good evening } \\ \text { Man } & : & \text { Don't you know how to say please? Children of today } \\ \text { Students } & : & \text { Please we are sorry }\end{array}$

In the Ghanaian diaspora, you just have to know some norms and should be a part of you. You will be taught both in school and home especially with the use of "please", "thank you", I am sorry", and also offering a helping to the elderly. This is seen in both examples. In the first dialogue the woman expected the girl to help her after she greeted but refused which is a sign of disrespect. She could have asked to offer help for the woman to either refuse or accept. The woman responded by accepting the impoliteness strategy the girl used.

Same applies to the use of "please" even when greeting that is why the man got offended in the second example. He responded to the impoliteness "Don't you know how to say please? Children of today" by accepted it. The students pleads for forgiveness by saying "please we are sorry".

\subsection{Bald-on-record Impoliteness}

Impoliteness work in bald on record impoliteness is carried in a very clear and obvious way. This strategy occurs when the speaker has an intention to attack the hearers face and when there is an adequate amount of face at risk (Culpeper 2003).

(A child cries for a chocolate and asks her mum to buy it)

$$
\begin{array}{lll}
\text { Child } & : & \text { Mama I want the chocolate } \\
\text { Mum } & : & \text { Shut up and stop crying! } \\
\text { Child } & : & \text { (stops crying and keep silent) }
\end{array}
$$

(A student is late for class, the teacher instructs him to leave the classroom)

$\begin{array}{lcl}\text { Teacher } & : & \text { Are you now coming to class? Leave } \\ \text { Student } & : & \text { Sir please... } \\ \text { Teacher } & : & \text { Leave! Else I will leave } \\ \text { Student } & : & \text { (silently walks out of the class) }\end{array}$

In the first example the mum performs a bald on record impoliteness by shouting at her son to keep mute " Shut up and stop crying!" . she does not try to be lenient with her child since she says it very clear. Furthermore, since she has power over the child, she commands him to stop crying. The child stops crying and refuse to respond by remaining silent "(stops crying and keep silent)".

The second example also depicts a bald on record where the teacher commands the student to leave the classroom since he has authority over him. Initially the student tried to plead with the teacher "sir please" but the teacher angrily tells him to exit else he will rather leave the classroom "Leave! Else I will leave". In response to the impoliteness strategy used by the teacher, the student walks out of the class without uttering a word " (silently walks out of the class)".

\section{Conclusion}

The first objective of this study is to find out the types of impoliteness strategies used in selected natural Ghanaian social interactions. The data of the research were grouped and analyzed based on the five impoliteness strategies proposed by Culpeper. The strategies are negative impoliteness, positive impoliteness, mock politeness, withhold impoliteness and bald on record impoliteness. The most frequently used strategy is the negative impoliteness with three occurrences followed by mock politeness, bald on record impoliteness and withhold impoliteness with two occurrences each then positive impoliteness with one occurrence.

The second objective is how impoliteness were linguistically represents with the use of vocatives ("you are not normal"), dismissals ("leave!", "You cant sit here" ), silencers ("Shut up and stop crying!"), threats ("Yes, else Nana Addo won't complete his term", 'if you dare'), statement of fault ("Good evening"). 
The third objective is the response to the impoliteness strategies used in a conversation. From the findings, four responses accept impoliteness, making it the most dominant. Three responses are countering defensively and one offensively because the want to save their faces .. two decided not to respond to prevent further attacks

\section{Recommendation}

Impoliteness under pragmatics has not gained much attention which means very few studies have been conducted. The researchers suggest that linguistics scholars and students will pay much attention and conduct studies on the phenomenon of impoliteness.

It is also suggested that future researchers will investigate the triggering factors on the use of impoliteness and use other data sources such interviews, movies, TV shows, radio shows and political talks.

Funding: This research received no external funding.

Conflicts of Interest: The authors declare no conflict of interest.

\section{References}

[1] Abbas A.N, Al-Majdawi A.M. (2018). A pragmatic analysis of impoliteness in selected British interviews. International Journal of Science and Research, 7(9), 536-542.

[2] Bennett, A., (1981). Interruptions and the interpretation of conversation. Discourse processes 4.171- 188.

[3] Bousfield, D. (2007a). Beginnings, middles and ends:A biopsy of the dynamics of impolite exchanges. Journal of Pragmatics, 39 (12), 2185 2216.https://.org/10.1016/j.pragma.2006

[4] Bousfield, D. (2007b). Impoliteness, preference organization and conducivity. Multilingua, 26(1), 1-33.

[5] Bousfield, D. (2008a). Impoliteness in interaction. Philadelphia: John Benjamins.

[6] Bousfield, D. (2008b). Impoliteness in the struggle for power. In D. Bousfield \& M.

[7] Cashman, L. (2006). Impoliteness in children's interaction in a Spanish/ English bilingual community of practice. Journal of Politeness Research 2, 217-246

[8] Culpeper, J. (1996). Towards an anatomy of impoliteness. Journal of Pragmatics 25,349-367

[9] Culpeper, J., Bousfield, D., \& Wichmann, A. (2003). Impoliteness revisited: with special reference to dynamic and prosodic aspects. Journal of Pragmatics, 35(10-11), 1545-1579.

[10] Culpeper, J. (2005). Impoliteness and entertainment in the television quiz show: The weakest link. Journal of Politeness Research, 1(1), 35-72. https://doi.org/10.1515/jplr.2005.1.1.35

[11] Culpeper, J. (2008). Reflections on impoliteness, relational work and power. In D. Bousfield \& M. A. Locher (Eds.), Impoliteness in Language: Studies on its Interplay with Power in Theory and Practice (pp.17-44). Berlin: Mouton de Gruyter

[12] Culperper, J (2011). Impoliteness: using language to cause offense. Cambridge University Press.

[13] Fordjour, E. A.(2016). Foul language in the Ghanaian electronic media a case study of some selected radio stations in Kumasi, Ghana. International Conference on Management, Communication and Technology, 4(1), 26-32.

[14] Forson, A. I., Fordjour, A. E., Tettey, A. L., and Oteng-Preko, E. (2017). Stylistic analysis of Akan insults: source, style and typology. International Journal of Management and Scientific Research, 1(4), 148-161

[15] Goffman, E. (1967). Interaction Ritual: Essays on face-to-face Behavior. New York:Anchor Books.

[16] Haugh, M. (2010). When is an email really offensive? Argumentativity and variability in evaluations of impoliteness. Journal of Politeness Research, 6, 7-31

[17] Işıı-Güler, H. (2008). Metapragmatics of (im)politeness: an exploratory emic investigation (Ph.D. dissertation). Ankara: Middle East Technical University.

[18] Kantara, A. (2010). Impoliteness strategies in "House M. D." Lodz Papers in Pragmatics, 6, 305-339

[19] Kienpointner, M. (2008). Impoliteness and emotional arguments. Journal of Politeness Research, 4(2), $243-265$. https://doi.org/10.1515/JPLR.2008.012

[20] Kryk-Kastovsky, B. (2006). Impoliteness in early modern English courtroom discourse. Journal of Historical Pragmatics, 7(2), 213-243

[21] Lakoff, R. 1989. The Limits of Politeness: Therapeutic and Courtroom Discourse. Multilingua 8, 101-129.

[22] Limberg, H. (2009). Impoliteness and threat responses. Journal of Pragmatics, 41, 1376-1394.

[23] Locher (Eds.), Impoliteness in language. Studies on its interplay with power in theory and practice (pp. 127-153). New York: Mouton de Gruyter

[24] Locher, M. A., \& Watts, R. (2008). Rational work and impoliteness. In D. Bousfield \& M. A. Locher (Eds.), Impoliteness in language: Studies on its interplay with power in theory and practice (pp. 77-100). Berlin, Germany: Mouton de Gruyter

[25] Mugford, G. (2008). How rude! Teaching impoliteness in the second-language classroom. ELT Journal, 62(4), 375-384. https://doi.org/10.1093/elt/ccm066.

[26] Mugford, G.(2018). Critical intercultural impoliteness. 'Where are you located ? Can you please transfer me to someone who is American?. Journal of Pragmatics 134(2018)173-182

[27] Nur, N. L.,(2006). A contrastive study of linguistic representation of impoliteness in French and Turkish. University of Huddersfield, UK

[28] Purnomo, A. P. (2015). Compliments and compliment responses used by English teacher association of senior high school in Pacitan (Master's thesis). Retrieved from http://eprints.ums.ac.id/33663/

[29] Thompson, R and Agyekum, K.(2016). Impoliteness: The Ghanaian Standpoint. International Journal of Society, culture \& Language, 4(1), 2033. 
[30] Spencer-Oatey, H. (2002). Managing rapport in talk: Using rapport sensitive incidents to explore the motivational concerns underlying the management of relations. Journal of Pragmatics, 34(5), 529-545. https://doi.org/10.1016/S0378-2166(01)00039-X.

[31] Spencer-Oatey, H. (2005). (Im)Politeness, face and perceptions of rapport: Unpackaging their bases and interrelationships. Journal of Politeness Research, 1(1), 95-119. https://doi.org/10.1515/.jplr.2005.1.1.95

Wijayanto, A., Hikamat, M. H., \& Prasetyarini, A. (2018). Impoliteness in English as a Foreign Language complaints: Exploring its intentions and motivating factors. Lingua Cultura, 12(1), 97-104. https://doi.org/10.21512/lc.v12i1.3635 